\title{
PROSPECTS OF SUGAR PRODUCTION AND IMPORTS: MEETING THE SUGAR DEMAND OF NIGERIA BY YEAR 2020
}

\author{
J.N. Nmadu, M.A. Ojo, F.D. Ibrahim, Researchers \\ Department of Agricultural Economics and Extension Technology \\ Federal University of Technology, Nigeria \\ E-mail: job nmadu@yahoo.co.uk, akinmikky@yahoo.co.uk, idfaith006@yahoo.com
}

\begin{abstract}
The trend of sugar cane production and refined sugar imports for the period 1960-2010 were analysed and forecasted to year 2020. Results show that sugar cane output will rise to $2.8 \mathrm{~m}$ tonnes from about 88 thousand hectares of land by year 2020. The total refined sugar that will be available from production and import is about 720 thousand tonnes but with Nigerian population growing at the rate of $2.27 \%$, potential demand for refined sugar will rise to $1.6 \mathrm{~B}$ tonnes by the year 2020 creating a deficit of over 1.5B tonnes. This require a drastic action which if not taken will lead to sugar crisis. Three major options are advocated in this paper i.e. hectarage expansion, massive funding of research to improve sugar cane production technology such that yield will rise to 150 tonnes per hectare and import expansion. Of the three options, only increase funding of research will encourage local technology and save Nigeria foreign exchange of more than $\$ 100 \mathrm{~B}$ annually and will make Nigeria self-reliant in sugar production by the year 2020 and facilitate the emergence of Nigeria as a developed nation.
\end{abstract}

\section{KEY WORDS}

Grafted model; Doubling time; Sugar; Production; Technology; Potential demand; Sugar crisis; Sugar deficit.

Sugarcane is the raw material used for manufacturing sugar in Nigeria which accounts for about $61 \%$ of the total world sugar production (Wayagari et al., 2003a,b). Two types of sugarcane are grown in Nigeria - industrial and soft (chewing) cane. The industrial cane is the hard or tough type generally processed into sugar by the sugar estates. The soft cane is mainly chewed raw for its sweet juice. Some of it is also processed into different crude sugar products. Local farmers grow soft cane all over Nigeria. Soft cane production accounts for about $60 \%$ of total sugarcane production in many years in Nigeria (Wayagari et. al., 1999). The exact total land area currently under cane cultivation and the total production in Nigeria is not known, but it is estimated at between 25,000-35,000 hectares, out of which soft cane covers 18,000 hectares. Average yield of soft cane on farmers' plots varies between 45-75 tonnes per hectare depending on management, varieties and inputs used. Globally the major use of the crop is in the manufacture of sugar. Sugar is used universally as a sweetener, blender and as a preservative. Major industrial users of the product include the pharmaceutical industries, the food and beverages industries, bakeries, soft drinks bottling plants as well as biscuit and other confectionery manufacturers. Domestically, it is used in large amounts as a table sweetener. Although a number of other by-products, e.g. bagasse, molasses, etc. are produced when sugarcane is processed, its major product and the one for which it is commercially cultivated is sugar. Nevertheless, cane production for chewing purpose is also of major commercial interest in Nigeria (Wayagari et. al., 1999). According to FAOSTAT (2011), Nigeria's accumulated import of sugar and sugar products in the last 50 years is valued at $\$ 8.18 \mathrm{~B}(\mathrm{~N} 1267.6 \mathrm{~B})$ showing that much of the sugar needs have been met through importation.

With growing population, the demand for sugar and sugar products is expected to rise but production seems to have stagnated for quite a while. Public and private investment in the sector is very low. Much of the production of sugar cane was carried out by the two government-controlled estates; Bacita in Kwara State and Numan in Adamawa State, both of which are now undergoing transformation from public to private ownership and are out of production. The number of refining factories are very low compared to other countries. For 
example, there are 571 factories in India, 45, in Brazil, 34 in the US (Alibaba.com, 2011, Economy Watch, 2011, FAO, 1997) while Nigeria has only one or two functional mills in addition to some localised farmers-level milling.. The other problem with Nigeria sugar industry is the low level of technology involved. In fact, the other sugar producing countries have started exploring the use of sugar for fuel (ethanol) away from the traditional food and confectionary use (USDA, 2006). The desire of the government is to make Nigeria the $20^{\text {th }}$ best economy by the year 2020. If that desire was to be achieved, in what ways will the sugar industry be affected and what are the likely policies needed to achieve this. In view of this, the main goal of this paper is to assess the general trend and future prospects of sugarcane production and sugar and sugar-related imports in Nigeria. The specific objectives are to estimate and compare the various trend equations of sugar cane production in Nigeria, determine the nature of the trend and forecast the trend to year 2020. Year 2020 is chosen because all policies in Nigeria are targeting the emergence of the country as a developed nation by that year. The study will provide opportunity to policy makers on the type of policies that are required to achieve the status of self-reliance in sugar production and a net exporter of sugar and sugar products by the year 2020 .

\section{METHODOLOGY}

Secondary data on sugar cane output, hectarage and yield as well as sugar and sugar-related imports for the period 1960 -2010 were obtained FAOSTAT(2011) and supplemented by CBN (2011). The data were analysed using growth and grafted models as well as linear and semilog equations. In modelling trend for this study the exponential trend or log-linear as employed by Ahmad et. al., 2005; Onyeaweaku and Okoye, 2005; Udom, 2006; Diebold, 2007; Ojiako et,al. 2007; Ojiako et, al. 2008 and Nmadu 2009 was employed. This functional form is also often phrased as "left-side semi-log by many econometricians according to Studenmund (2001). The function is given as:

$$
\mathrm{S}_{\mathrm{V}}=\mathrm{ae} \mathrm{e}^{\mathrm{bt}}
$$

Eq. (1) is linearised by taking its natural logarithm to make it amenable to OLS to obtain:

$$
\ln S_{v}=a+b t+u \quad(2)
$$

where: $S_{V}=$ Various sugar variables

$$
\begin{aligned}
& \text { i. } \quad \text { Sugar cane output in '000 tonnes } \\
& \text { ii. } \quad \text { Sugar cane hectarage in '000 ha } \\
& \text { iii. } \quad \text { Sugar cane yield in ' } 000 \mathrm{~kg} / \mathrm{ha} \\
& \text { iv. } \quad \text { Refined sugar imports in '000 tonnes } \\
& \mathrm{v} . \quad \text { Other sugar related imports in '000 tonnes } \\
& \mathrm{t}=\text { trend variable } 1960-2010 \\
& \mathrm{u}=\text { noise term nid }\left(0, \Phi^{2}\right)
\end{aligned}
$$

After the estimation of eq. (2), the compound rate of growth was computed as follows:

$$
r=\left(e^{b}-1\right) \times 100 \quad(3)
$$

where: $r=$ compound rate of growth; $\quad b=$ estimated coefficient from eq. (2). The time it will take to double the rate of growth was then estimated as given below:

$$
\mathrm{D}_{\mathrm{T}}=69 / \mathrm{r} \quad(4),
$$

where $D_{T}=$ doubling time; $r=$ compound rate of growth computed in eq. (3). 
In order to determine the nature of growth of the various variables, a quadratic function in the trend variable was estimated as follows:

$$
\ln S_{v}=a+b t+c t^{2}+u
$$

All variables as previously defined. The quadratic trend term in eq. (5) allows for the possibility of determining deceleration, acceleration or stagnation in sugar economy in Nigeria during the period under study. Significant positive value indicates acceleration in growth; significant negative value indicates deceleration in growth while non-significant value implies stagnation in the growth process (Sawant, 1981; Onyenweaku, 1993).

To be able to estimate the grafted model, a graphical examination of the various time series data was under taken to determine the type of grafted equation and the various joint points. The Table below gives the type and Joint Point (JP) of the data sets (Nmadu et. al., 2009).

Table 1. Suggested graft and Joint Points of various variables

\begin{tabular}{|c|c|c|c|}
\hline Variable & Graft suggested & $\mathrm{JP}_{1}$ & $\mathrm{JP}$ \\
\hline Sugar cane output & Linear - quadratic - Linear & 1993 & 2007 \\
\hline Sugar cane yield & Linear - quadratic - Linear & 1965 & 2002 \\
\hline Sugar cane hectarage & Linear - quadratic - Linear & 1981 & 2002 \\
\hline Refined sugar imports & Linear - quadratic - Linear & 1981 & 2007 \\
\hline Sugar related imports & Linear - quadratic - Linear & 1995 & 2005 \\
\hline
\end{tabular}

From the Table 1, it can be observed that all the series can be divided into three segments; hence the following trend function was suggested:

$$
\begin{array}{ll}
Y_{t}=\alpha_{0}+\beta_{0} t, & t \leq J P_{1} \\
Y_{t}=\alpha_{1}+\beta_{1} t+\phi_{1} t^{2}, & J P_{1}<t \leq J P_{2} \\
Y_{t}=\alpha_{2}+\beta_{2} t, & t>J P_{2}
\end{array}
$$

Where: $Y_{t}=$ sugar variables in year $\mathrm{t}$;

$\mathrm{t}=$ trend, $1960-2010$;

$\alpha$ 's, B's and $\phi=$ structural parameters to be estimated;

$\mathrm{JP}_{1}$ and $\mathrm{JP}_{2}=$ Joint Point 1 and 2 respectively.

The above equations are then reworked as shown below:

$$
\begin{aligned}
& Y_{t}=\alpha_{2}+B_{2} t+\phi_{1}\left(J P_{2}{ }^{2}-J P_{1}{ }^{2}+-2\left(J P_{2}\right) t+2\left(J P_{1}\right) t\right), t \leq J P_{1} \\
& Y_{t}=\alpha_{2}+B_{2} t+\phi_{1}\left(J P_{2}^{2}-2\left(J P_{2}\right) t+t^{2}\right), \quad J P_{1}<t \leq J P_{2} \\
& Y_{t}=\alpha_{2}+B_{2} t, \quad t>J P_{2}
\end{aligned}
$$

The above equations, (9), (10) and (11), are then formed into a single equation for estimation as follows:

$$
Y_{t}=\mu_{o} Z_{o}+\mu_{1} Z_{1}+\mu_{1} Z_{2}+U_{t}
$$

where: $Z_{0}=1$,

$Z_{1}=\mathrm{t}$ $\forall \mathrm{t}, \forall=$ for all

$Z_{2}=J P_{2}^{2}-J P_{1}^{2}-2 t\left(J P_{2}-J P_{1}\right)$

$\forall \mathrm{t}$

$$
=(\mathrm{t}-\mathrm{JP})^{2} \text {, }
$$

$=0$,

$\mathrm{t} \leq \mathrm{JP}_{1}$

$J P_{1}<t \leq J P_{2}$

$U_{t}=$ error term assumed to be well behaved.

Equation (12) was then estimated using OLS and the output forecasted to year 2020. See Nmadu, 2010 and 2002 as well as Fuller, 1969 for details of equations (8) - (12). 
In addition to the grafted equation above, the linear and semilog forms of all the series were estimated, forecasted to 2020 and compared with the other equations. The models are:

$$
\begin{array}{ll}
S_{t}=a+b t & \text { (linear) } \\
S_{t}=a+b \ln t & \text { (semilog) }
\end{array}
$$

After the estimation, the adequacy of each of the models was determined using Root Mean Square Error (RMSE), Mean Absolute Deviation (MAD), Mean Absolute Percentage Error (MAPE), Theil's inequality coefficient (U) and Percent Turning Point Error (PTPE) in line with Yu and Ren (2011) and Swanson et. al. (2011).

\section{RESULTS AND DISCUSSION}

The basic statistics of the various variables and their 2020 forecasts are presented on Table 2. The estimates of all the coefficients of the various models regarding sugar cane production as well as refined sugar import are presented on Tables 3-7 while the computed compound rates and doubling times are presented on Table 8. The diagnostics of the various models are presented on Tables 9-13. Figures 1-5 show the predicted variables and the forecasts to year 2020 .

Table 2. Basic statistics of the variables in the analysis

\begin{tabular}{|c|c|c|c|c|c|c|c|c|c|}
\hline Variable & Mean & Std. Dev. & Min & Max & \multicolumn{5}{|c|}{2020 forecast } \\
\hline Sugar cane output & 1074 & 1171 & 160 & 6442 & 2800 & 782 & 775 & 2010 & 4413 \\
\hline Sugar cane hectarage & 25 & 16 & 6 & 85 & 88 & 55 & 55 & 66 & 81 \\
\hline Can sugar yield & 331 & 71 & 188 & 411 & 47 & 265 & 266 & 256 & 98 \\
\hline Sugar related imports & 191 & 363 & 4 & 1371 & 9053 & 2781 & 2765 & 2962 & 3711 \\
\hline Refined sugar imports & 381 & 271 & 32 & 1099 & 300 & 813 & 811 & 1599 & 180 \\
\hline
\end{tabular}

The results in Tables 3-7 show that all the coefficients are significant in explaining the variation in each of the variables. The results shows that the F-ratios were significant at the $1 \%$ level. In addition the adjusted $\mathrm{R}^{2}$ varies from $13 \%$ to $98 \%$. The result revealed that both the F-ratio and the adjusted $R^{2}$ were quite larger with the grafted model in almost all the cases. In addition, Tables 9-13 show that the grafted model possessed superior forecasting qualities than the other models. These qualities are also evident as revealed on Figs. 1-5. Figires also show that the grafted model better simulated the historical trend of the variables and gave a more realistic forecasts of the variables. In view of this, the grafted model is chosen as the lead equation and is used for further analysis.

\begin{tabular}{|c|c|c|c|c|c|}
\hline- & $\mu_{0}$ & $\mu_{1}$ & $\mu_{2}$ & Adj. R2 & F-ratio \\
\hline Linear model & $\begin{array}{l}-95776.6^{\star \star \star} \\
(17545.03)\end{array}$ & $\begin{array}{c}48.79^{\star \star \star} \\
(8.83)\end{array}$ & - & 0.37 & $30.47^{\star \star \star}$ \\
\hline Semilog model & $\begin{array}{l}-732617^{\star \star \star} \\
(133407.9)\end{array}$ & $\begin{array}{c}96622.81^{\star 1 \times} \\
(17569.05)\end{array}$ & - & 0.33 & $25.999^{* * *}$ \\
\hline Growth model & $\begin{array}{c}-68.32^{\star \star \star \star} \\
(8.60)\end{array}$ & $\begin{array}{l}0.0378^{\star \star \star} \\
(0.00434)\end{array}$ & - & 0.60 & $75.96^{\star \star *}$ \\
\hline Growth square model & $\begin{array}{c}812.10^{\mathrm{n}} \\
(1305.23)\end{array}$ & $\begin{array}{l}-0.85^{\mathrm{n} \overline{\mathrm{s}}} \\
(1.32)\end{array}$ & $\begin{array}{l}0.000223^{15} \\
(0.000331)\end{array}$ & 0.595 & $37.78^{\star \star \star}$ \\
\hline Grafted model & $\begin{array}{c}-855820 \\
(65441.34)\end{array}$ & $\begin{array}{c}428.15^{\star \star \star} \\
(32.67)\end{array}$ & $\begin{array}{c}15.41^{* \star \star \star} \\
(1.31)\end{array}$ & 0.83 & $126.43^{\star * *}$ \\
\hline
\end{tabular}

Table 3. Estimated coefficients of the various forecasting models for output of sugar cane

NB: Values in parenthesis are standard errors, ${ }^{* * * *}=P<0.01$

Source: CBN, 2009, FAOSTAT, 2010. 
Table 4. Estimated coefficients of the various forecasting models for hectarage of sugar cane

\begin{tabular}{|c|c|c|c|c|c|}
\hline- & $\mu_{\mathrm{o}}$ & $\mu_{1}$ & $\mu_{2}$ & Adj. R2 & F-ratio \\
\hline Linear model & $\begin{array}{c}-1670.23^{\star \star \star} \\
(193.99)\end{array}$ & $\begin{array}{l}0.854^{* \star \star} \\
(0.0977)\end{array}$ & - & 0.60 & $76.38^{\star \star \star}$ \\
\hline Semilog model & $\begin{array}{c}-12826.8^{\star \star \star} \\
(1476.70)\end{array}$ & $\begin{array}{c}1692.52^{\star \star \star} \\
(194.47)\end{array}$ & - & 0.599 & $75.74^{\star \star *}$ \\
\hline Growth model & $\begin{array}{c}-60.49^{* \star \star} \\
(4.82)\end{array}$ & $\begin{array}{c}0.032^{\star \star \star} \\
(0.00243)\end{array}$ & - & 0.775 & $87.63^{\star \star \star}$ \\
\hline Growth square model & $\begin{array}{l}712.14^{\text {ns }} \\
(726.56)\end{array}$ & $\begin{array}{l}-0.746^{\mathrm{ns}} \\
(0.732)\end{array}$ & $\begin{array}{l}0.000196^{\mathrm{s}} \\
(0.000184)\end{array}$ & 0.776 & $173.67^{\star \star *}$ \\
\hline Grafted model & $\begin{array}{c}-5034.67^{\star \star \star} \\
(490.16)\end{array}$ & $\begin{array}{c}2.54^{\star \star \star} \\
(0.25)\end{array}$ & $\begin{array}{l}0.059^{\star \star \star} \\
(0.0083)\end{array}$ & 0.80 & $102.75^{\star \star *}$ \\
\hline
\end{tabular}

NB: Values in parenthesis are standard errors, ${ }^{* * * *}=P<0.01$

Source: CBN, 2009, FAOSTAT, 2010.

Table 5. Estimated coefficients of the various forecasting models for yield of sugar cane

\begin{tabular}{|c|c|c|c|c|c|}
\hline- & $\mu_{o}$ & $\mu_{1}$ & $\mu_{2}$ & Adj. R2 & F-ratio \\
\hline Linear model & $\begin{array}{c}4027.13^{\star \star \star} \\
(1250.23)\end{array}$ & $\begin{array}{c}-1.862^{\star \star \star \star} \\
(0.63)\end{array}$ & - & 0.13 & $8.74^{\star \star \star}$ \\
\hline Semilog model & $\begin{array}{c}28206.11^{* *} \\
(9504.38)\end{array}$ & $\begin{array}{c}-3671.05^{\star \star} \\
(1251.67)\end{array}$ & - & 0.132 & $8.60^{* * *}$ \\
\hline Growth model & $\begin{array}{c}18.69^{\star \star \star} \\
(4.17)\end{array}$ & $\begin{array}{c}-0.0065^{\star \star \star} \\
(0.0021)\end{array}$ & - & 0.15 & $9.61^{* \star *}$ \\
\hline $\begin{array}{l}\text { Growth square } \\
\text { model }\end{array}$ & $\begin{array}{c}-3725.95^{\star \star \star} \\
(332.99)\end{array}$ & $\begin{array}{l}3.77^{\star \star \star} \\
(0.336)\end{array}$ & $\begin{array}{l}-0.00095 \\
(8.45 E-05)\end{array}$ & 0.76 & $80.34^{\star \star \star}$ \\
\hline Grafted model & $\begin{array}{c}25379.05^{\star \star \star} \\
(1706.08)\end{array}$ & $\begin{array}{c}-12.54^{* \star \star} \\
(0.854)\end{array}$ & $\begin{array}{l}-0.311^{\star * \star} \\
(0.02337)\end{array}$ & 0.81 & $108.77^{\star \star *}$ \\
\hline
\end{tabular}

NB: Values in parenthesis are standard errors, ${ }^{* * * *}=P<0.01$

Source: CBN, 2009, FAOSTAT, 2010.

Table 6. Estimated coefficients of the various forecasting models for refined sugar imports

\begin{tabular}{|c|c|c|c|c|c|}
\hline & $\mu_{0}$ & $\mu_{1}$ & $\mu_{2}$ & Adj. R2 & F-ratio \\
\hline Linear model & $\begin{array}{c}-24132.7^{\star \star \star} \\
(3799.58)\end{array}$ & $\begin{array}{c}12.35^{\star \star \star} \\
(1.91)\end{array}$ & & 0.448 & $41.63^{* * *}$ \\
\hline Semilog model & $\begin{array}{l}-186041^{\star \star \star} \\
(28811.81)\end{array}$ & $\begin{array}{c}24550.77^{\star * \star} \\
(3794.35)\end{array}$ & & 0.449 & $41.87^{\star * *}$ \\
\hline Growth model & $\begin{array}{l}-96.96^{\star * \star} \\
(12.015)\end{array}$ & $\begin{array}{l}0.05165^{\star \star \star} \\
(0.006053)\end{array}$ & & 0.60 & $72.82^{\star * *}$ \\
\hline Growth square model & $\begin{array}{l}-8640.1^{* \star *} \\
(1353.99)\end{array}$ & $\begin{array}{c}8.66^{\star \star \star} \\
(1.36)\end{array}$ & $\begin{array}{l}-0.00217^{\star \star \star} \\
(0.000344)\end{array}$ & 0.77 & $19.24^{\star \star \star}$ \\
\hline Grafted model & $\begin{array}{l}32130.48^{\star \star} \\
(15099.71)\end{array}$ & $\begin{array}{c}-15.76^{\star \star} \\
(7.55)\end{array}$ & $\begin{array}{c}-0.7396^{\star \star \star} \\
(0.19351)\end{array}$ & 0.568 & $33.90^{* * *}$ \\
\hline
\end{tabular}

NB: Values in parenthesis are standard errors, ${ }^{* * *}=P<0.01,{ }^{* *}=P<0.05$ Source: CBN, 2009, FAOSTAT, 2010.

Table 7. Estimated coefficients of the various forecasting models for other sugar-related imports

\begin{tabular}{|c|c|c|c|c|c|}
\hline- & $\mu_{0}$ & $\mu_{1}$ & $\mu_{2}$ & Adj. R2 & F-ratio \\
\hline Linear model & $\begin{array}{c}-33289.2^{\star \star \star} \\
(5001.11)\end{array}$ & $\begin{array}{c}16.87^{\star \star \star} \\
(2.52)\end{array}$ & - & 0.467 & $44.82^{\star \star \star}$ \\
\hline Semilog model & $\begin{array}{c}-25333^{\star \star \star} \\
(38067.29)\end{array}$ & $\begin{array}{c}33387.64^{* * *} \\
(5013.24)\end{array}$ & - & 0.464 & $44.35^{\star \star \star}$ \\
\hline Growth model & $\begin{array}{c}-214.40^{\star \star \star} \\
(10.81)\end{array}$ & $\begin{array}{c}0.1099^{\star * \star} \\
(0.005446)\end{array}$ & - & 0.89 & $407.23^{\star * *}$ \\
\hline Growth square model & $\begin{array}{c}5211.57^{\star \star \star} \\
(1449.67)\end{array}$ & $\begin{array}{c}-5.36^{\star \star \star} \\
(1.46)\end{array}$ & $\begin{array}{l}0.00138^{\star \star \star} \\
(0.000368)\end{array}$ & 0.91 & $264.68^{* * *}$ \\
\hline Grafted model & $\begin{array}{c}-274890^{* * \star} \\
(7127.63)\end{array}$ & $\begin{array}{c}137.47^{\star \star \star} \\
(3.56)\end{array}$ & $\begin{array}{l}6.82^{\star \star \star} \\
(0.199)\end{array}$ & 0.98 & $1144.098^{\star \star \star}$ \\
\hline
\end{tabular}

NB: Values in parenthesis are standard errors, ${ }^{* * *}=P<0.01$ Source: CBN, 2009, FAOSTAT, 2010. 
The result on Table 8 shows that only sugar-related import is accelerating given the current trend and is growing at the rate of $11.62 \%$ per annum and will double by the year 2016. Sugar cane output and hectarage had stagnated at the current trend but are growing at the rate of $3.85 \%$ and $3.25 \%$ per annum respectively. Output will double by the year 2028 while hectarage will double by the year 2031. In addition, yield of sugar cane and refined sugar import shows deceleration at the current rate although, while refined sugar import still has positive growth rate of $5.30 \%$ per annum, yield per ha of sugar cane shows negative growth of $-0.6 \%$ and suggest that the sugar cane production technology in Nigeria is as old as 1904. The low growth in sugar cane technology must have accounted for the stagnation in output. In this entire scenario, it therefore means that for Nigeria to be self-reliant in sugar production there is need to improve production technology massively in order to meet increasing demand occasioned by increase population and improved status. In that case, the policy options will be such that refined sugar imports will be slowed while output and hectarage would have to be accelerated to be able to achieve self-sufficiency by the year 2020. In the case of yield per ha, research must be stepped up and funds made available to develop sugar cane lines that will be able to increase output massively without necessarily expanding hectarage.

Table 8. Compound rate, doubling time and nature of growth of the various variables

\begin{tabular}{|c|c|c|c|c|}
\hline- & $\begin{array}{c}\text { Compound } \\
\text { growth rate }\end{array}$ & $\begin{array}{c}\text { Doubling time } \\
\text { (years) }\end{array}$ & $\begin{array}{c}\text { Year doubling } \\
\text { would be achieved }\end{array}$ & Type of growth \\
\hline Output & 3.85 & 18 & 2028 & Stagnation \\
\hline Hectarage & 3.25 & 21 & 2031 & Stagnation \\
\hline Yield & -0.6 & -106 & 1904 & Deceleration \\
\hline Refined sugar import & 5.30 & 13 & 2023 & Deceleration \\
\hline-9 Other sugar-related import & 11.62 & 6 & 2016 & Acceleration \\
\hline
\end{tabular}

Table 9. Validity statistics of the estimated models for sugar cane output

\begin{tabular}{|c|c|c|c|c|c|c|}
\hline- & PTPE & MSE & RMSE & $\mathrm{MAD}$ & $\mathrm{MAPE}$ & Theil \\
\hline Linear & 0.1569 & 829376.38 & 910.70 & 561.40 & 0.6627 & 0.3171 \\
\hline Semilog & 0.1569 & 831757.93 & 912.01 & 561.93 & 0.6629 & 0.3176 \\
\hline Growth & 0.1569 & 782878.36 & 884.80 & 445.99 & 0.3957 & 0.3373 \\
\hline Growth square & 0.1569 & 713623.49 & 844.76 & 436.25 & 0.4063 & 0.3195 \\
\hline Grafted & 0.5686 & 214611.28 & 463.26 & 339.91 & 0.4925 & 0.1498 \\
\hline
\end{tabular}

Table 10. Validity statistics of the estimated models for sugar cane hectarage

\begin{tabular}{|c|c|c|c|c|c|c|}
\hline- & PTPE & MSE & RMSE & MAD & MAPE & Theil U \\
\hline Linear & 0.2549 & 101.40 & 10.07 & 6.83 & 0.2788 & 0.1738 \\
\hline Semilog & 0.2549 & 101.91 & 10.10 & 6.84 & 0.2794 & 0.1743 \\
\hline Growth & 0.2549 & 78.46 & 8.86 & 5.58 & 0.2153 & 0.1573 \\
\hline Growth square & 0.2549 & 64.82 & 8.05 & 5.20 & 0.2132 & 0.1421 \\
\hline Grafted & 0.2549 & 49.13 & 7.01 & 5.48 & 0.2691 & 0.1191 \\
\hline
\end{tabular}

Table 11. Validity statistics of the estimated models for sugar cane yield

\begin{tabular}{|c|c|c|c|c|c|c|}
\hline- & PTPE & $\mathrm{MSE}$ & RMSE & $\mathrm{MAD}$ & MAPE & Theil U \\
\hline Linear & 0.64706 & 4211.36 & 64.89 & 53.80 & 0.1844 & 0.0969 \\
\hline Semilog & 0.64706 & 4221.64 & 64.97 & 53.91 & 0.1848 & 0.0970 \\
\hline Growth & 0.64706 & 4425.90 & 66.53 & 55.19 & 0.1838 & 0.1003 \\
\hline Growth square & 0.45098 & 810.00 & 28.46 & 21.61 & 0.0790 & 0.0423 \\
\hline Grafted & 0.45098 & 897.07 & 29.95 & 22.16 & 0.0825 & 0.0444 \\
\hline
\end{tabular}

Table 12. Validity statistics of the estimated models for refined sugar imports

\begin{tabular}{|c|c|c|c|c|c|c|}
\hline - & PTPE & $\mathrm{MSE}$ & RMSE & $M A D$ & $\mathrm{MAPE}$ & Theil U \\
\hline Linear & 0.39216 & 38897.00 & 197.22 & 154.02 & 0.7162 & 0.2220 \\
\hline Semilog & 0.39216 & 38794.92 & 196.96 & 153.67 & 0.7122 & 0.2217 \\
\hline Growth & 0.39216 & 64341.13 & 253.66 & 180.55 & 0.5752 & 0.2846 \\
\hline Growth square & 0.37255 & 30957.42 & 175.95 & 125.05 & 0.4053 & 0.2049 \\
\hline Grafted & 0.39216 & 29821.46 & 172.69 & 136.24 & 0.6158 & 0.1921 \\
\hline
\end{tabular}


Table 13. Validity statistics of the estimated models for sugar-related imports

\begin{tabular}{|c|c|c|c|c|c|c|}
\hline- & PTPE & MSE & RMSE & $M A D$ & MAPE & Theil U \\
\hline Linear & 0.3725 & 67386.88 & 259.59 & 204.61 & 8.6822 & 0.3604 \\
\hline Semilog & 0.3725 & 67723.22 & 260.24 & 204.99 & 8.6794 & 0.3616 \\
\hline Growth & 0.3725 & 45973.69 & 214.41 & 98.63 & 0.4971 & 0.3470 \\
\hline Growth square & 0.3725 & 15247.11 & 123.48 & 60.92 & 0.3914 & 0.1732 \\
\hline Grafted & 0.3725 & 2650.98 & 51.49 & 27.08 & 0.4931 & 0.0635 \\
\hline
\end{tabular}

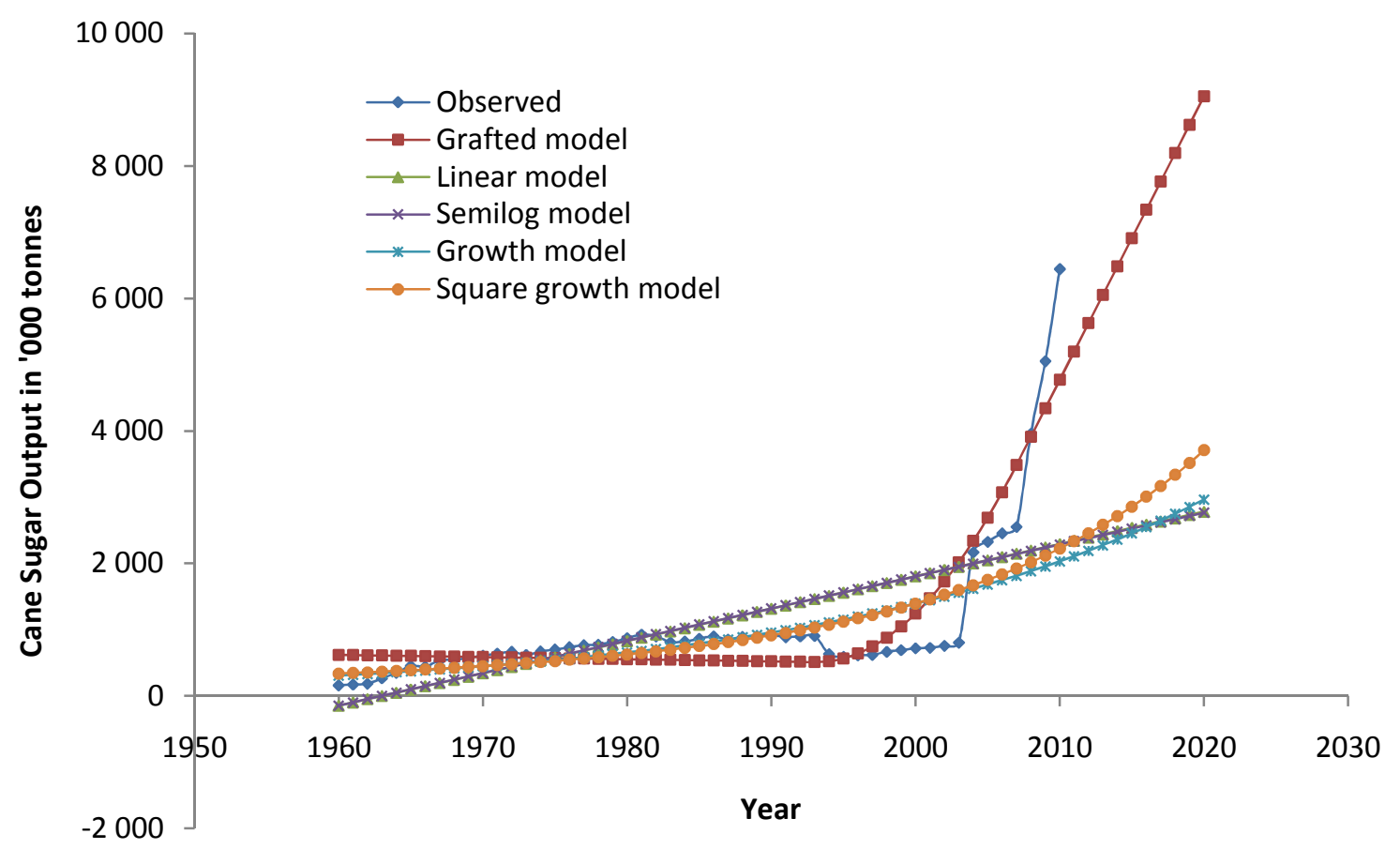

Figure 1. Estimated models of the past trend and forecast of sugar cane output in Nigeria (1960-2010)

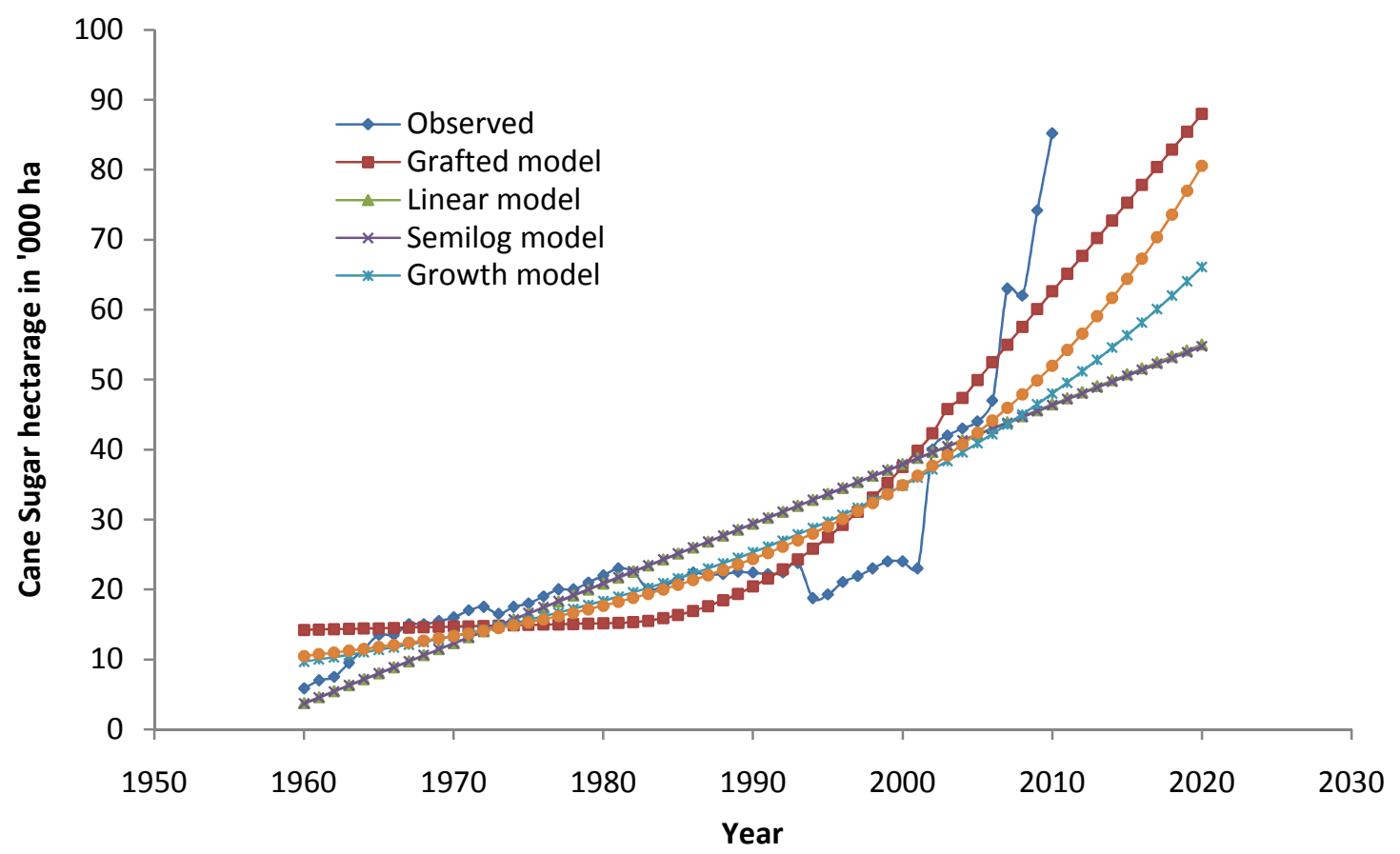

Figure 2. Estimated models of the past trend and forecast of sugar cane hectarage in Nigeria $(1960-2010)$ 


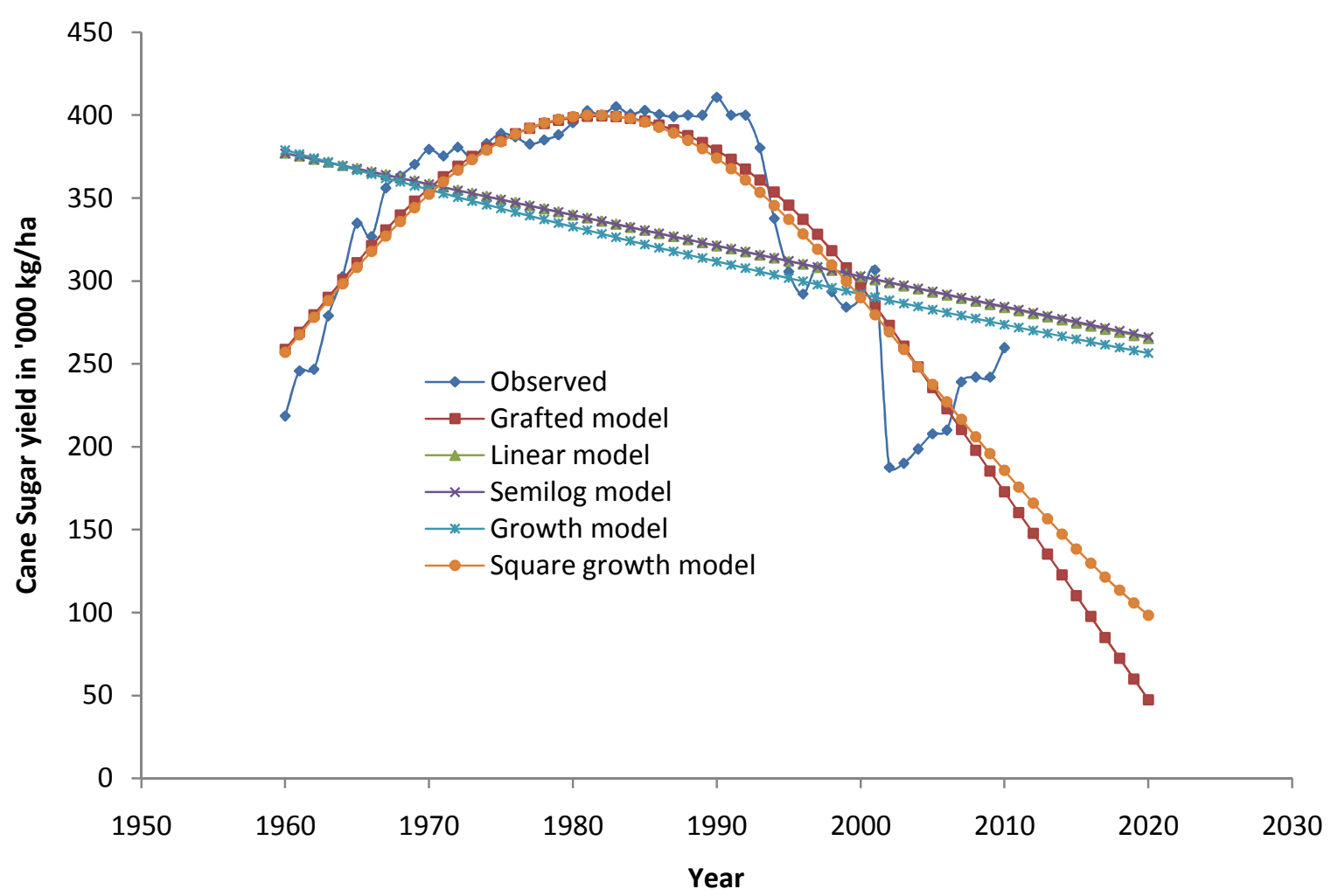

Figure 3. Estimated models of the past trend and forecast of sugar cane yield in Nigeria (1960-2010)

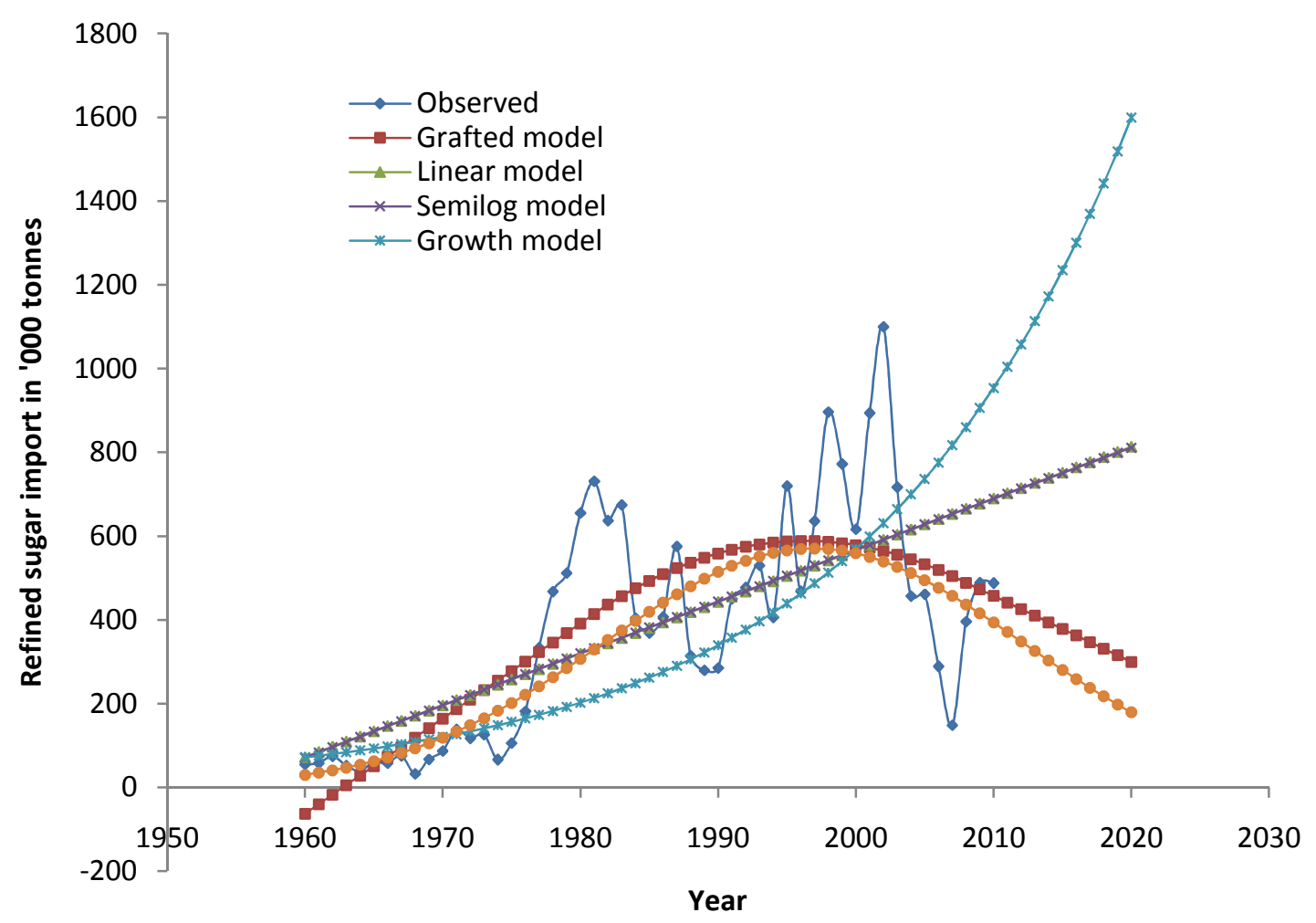

Figure 4. Estimated models of the past trend and forecast of refined sugar import in Nigeria (1960-2010) 


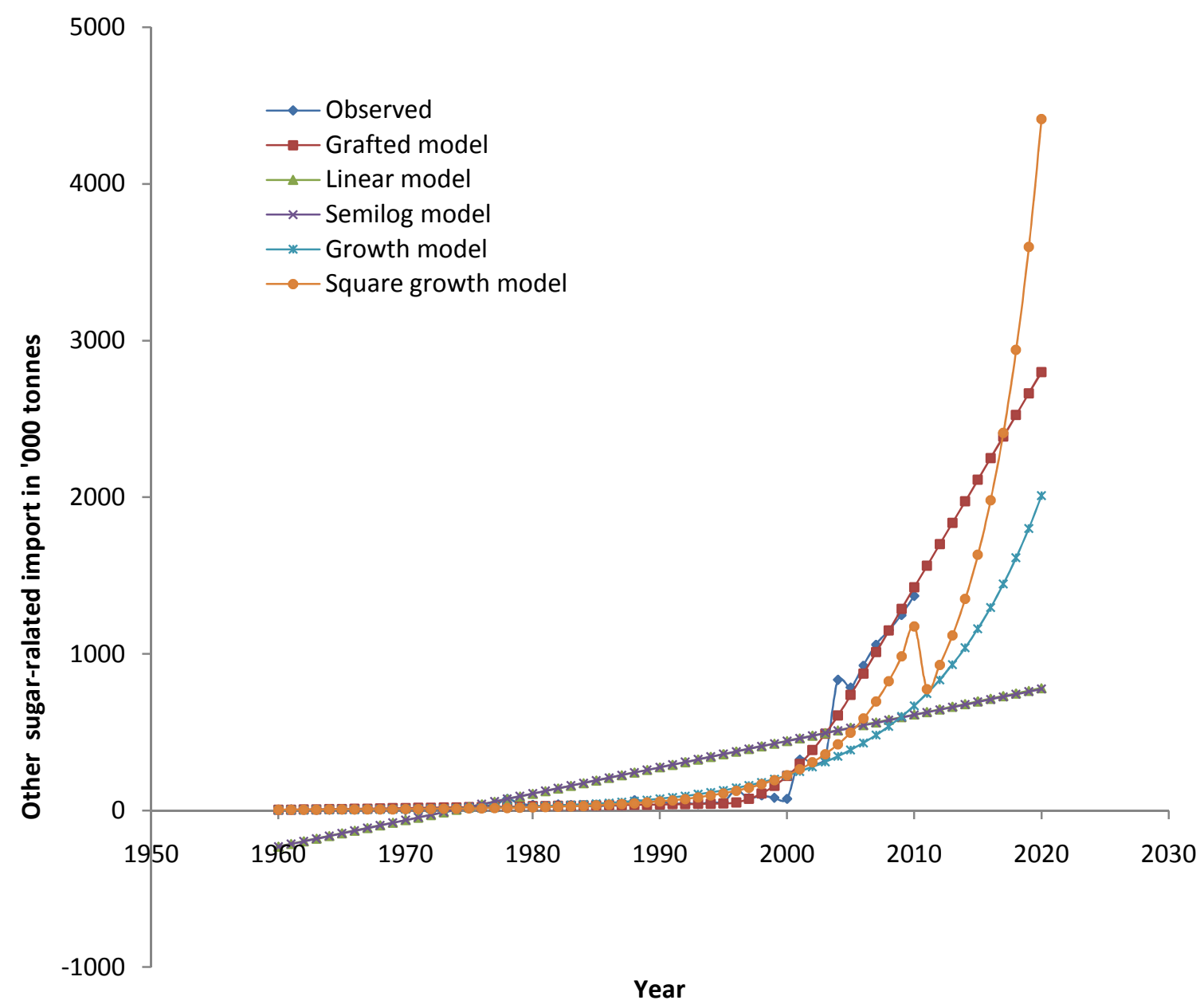

Figure 5. Estimated models of the past trend and forecast of other sugar-related import in Nigeria $(1960-2010)$

The population of Nigeria, which is $140 \mathrm{~m}$ (NPC, 2006) with the growth rate of $2.27 \%$ will grow to about $194 \mathrm{~m}$ by the year 2020 given the potential demand for refined sugar growing from 1.1B tonnes to $1.6 \mathrm{~B}$ tonnes in line with recommended daily sugar intake per adult (Rodale, 2011, e-how Health, 2011). This potential demand is a far cry from the grafted model's forecast values of both the production and imports put together (i.e. 720 tonnes), creating a very huge deficit. Therefore appropriate policies are needed to boost the sugar sector such that by the year 2020, Nigeria's sugar demand will be fully met. If the needed policy favours increased local production as against importation, then sugar cane hectarage must be increased from the current rate of 88 thousand hectares to 782 thousand hectares. Conversely, instead of contemplating massive hectarage expansion, Nigeria can massively fund research to improve sugar cane production technology and raise the yield per hectare to not less than 150 tonnes per ha up from the present 47 tonnes and that reduces the needed hectarage to 246 thousand. This must be complemented by the rehabilitation of the existing sugar estates and private-sector driven establishing of new estates so that the refining capacity of Nigeria will be able to meet the demand and possibly exports of surplus. The overall benefit of all these policies would be the full take-off of commercial sugar production in Nigeria and creation of employment opportunities for the teaming unemployed youths and graduates. The second option is less expensive on the long run as it will drastically reduce the cost of production and will encourage new investors to join the sector.

The second major policy to contemplate is import expansion. This, even though is much easier and simpler to undertake, has the potential to weaken local production, further slow down sugar production technology in Nigeria and also serve as a drainpipe of the 
nation's scarce resources. Indeed the cost of potential sugar imports by Nigeria will rise from

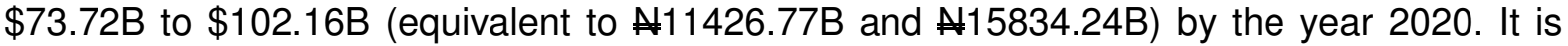
clear that import expansion is not a good option since if pursued it means that $100 \%$ of the annual budget would be spent on sugar importation. However, whatever policy option that may be contemplated, now is the time to act in order to avoid a major sugar crisis in Nigeria (i.e. a sugar deficit of over 1.5B tonnes by the year 2020 if production and imports are maintained at the current trend) and ensure that the proposed emergence of Nigeria as a developed nation by the year 2020 is fully achieved.

\section{CONCLUSION}

The trend of sugar cane production as well as imports of refined and other related sugar from 1960 to 2010 was studied using grafted model and growth model. It was found that based on the current trend, there will be sugar deficit by the year 2020 if nothing is done now. Three major options are advocated in this paper i.e. hectarage expansion, massive funding of research to improve sugar cane production technology such that yield will rise to 150 tonnes per hectare and importation expansion. Of the three options, only increase funding of research will encourage local technology and save Nigeria of foreign exchange that will otherwise be spent on importation.

\section{ACKNOWLEDGEMENTS}

The Authors wish to thank the anonymous reviewers for their critical assessment of the paper and the constructive criticisms and suggestions.

\section{REFERENCES}

[1] Ahmad, B., Ghafoor, .A. and Badar, H. (2005): Forecasting and growth trends of production and export of Kinnow from Pakistan. Journal of Agriculture and social sciences vol 1, no 1.

[2] Aide N. and S. Bardet, (2007). Would Patient Selection Based on Both Calcitonin Blood Level and Doubling Time Improve 18F-FDG PET Sensitivity in Restaging of Medullary Thyroid Cancer? The Journal of Nuclear Medicine, Vol. 48(9):1574. DOI: 10.2967/jnumed.107.044248.

[3] Alibaba.com (2011). http://www.alibaba.com/showroom/sugar-mills-in-brazil.html, September, 10.

[4] Anyeabgunam, A.N., Onwmere,.J. and Korieocha, D.S. (2006): Comparative trends analysis of yam and cassava in Nassarawa state, Nigeria (1996-1997/2005/2006). In Asumugha, G.N., Olojede, A.O., Ikeorgu, J.G., Ano,.A.O.and Herbert U. (eds).

[5] CBN (2011). Statistical Bulletin, 2009. Retrieved from http://www.cenbank.org/documents/Statbulletin.asp on April 10.

[6] Daily trust newspaper (2009): Nigeria: 'The problem with sugar production in the country' $16^{\text {th }}$ September, 2009.

[7] Diebold, F.X. (2007) Elements of forecasting $4^{\text {th }}$ ed., Cincinnati, Ohio: South Western College Publishing.

[8] Economy Watch (2011). Indian Sugar Industry. Retrieved from http://www.economywatch.com/business-and-economy/sugar-industry.html on September 10.

[9] e-how Health (2011). What is a Healthy Sugar Intake Per Day. Retrieved from http://www.ehow.com/about_5526875_healthy-sugar-intake-per-day.html on May 24.

[10] FAO, (1997). The north American sugar market: recent trends and prospects beyond 2000. Proceedings of Fij/FAO Asia Pacific Sugar Conference Fiji, 29-31 October. Retrieved from http://www.fao.org/DOCREP/005/X0513E/x0513e15.htm on September 10.

[11] FAOSTAT (2011). http://faostat.fao.org. 
[12] Mohammed, .T. and Ahmadi,.S. (2008): Estimating growth rates and decomposition analysis of A gricultural production in Iran (1970-2000). Trends of agricltural economics 1 (1): 14-26.

[13] Nmadu, J.N. (2009) Effect of changes on some macroeconomic policies on sorghum economy in Nigeria between 1961-2005.

[14] Nmadu, J.N., E.S. Yisa and U. S. Mohammed (2009). Spline Functions: Assessing their Forecasting Consistency with Changes in the Type of Model and Choice of Joint Points. Trends in Agricultural Economics 2(1):17-27 (http://scialert.net/pdfs/tae/2009/17-27.pdf, DOI: 10.3923/tae.2009.17.27).

[15] Ojiako, .I.A., Asumugha, .G.N., Ezedinma, C. (2008): Analysis of production trends in Nigeria's major cereals, 1961-2005,. Research on crops, vol 9, no 2 (August), 2008.

[16] Ojiako, .I.A., Asumugha, .G.N., Ezedinma, C. and Uzokwe, N.E. (2007): Analysis in the production trends in the major root and tuber crops in Nigeria, 1961-2005. Research on crops vol 8, no 2 (August), 2007: 371-380.

[17] Onyenweaku, C.E., and Okoye, B.C. (2005): Trends in cassava output, area and productivity in Nigeria, 1960/61 2003/04. In Orheruata, A.M., Nwokoro, S.O., Ajayi, M.T., and Asumugha, G.N. (eds). Agricultural Rebirth for improved production in Nigeria. Proceeding of the $39^{\text {th }}$ annual conference of the Agricultural society of Nigeria held at the University of Benin, Benin City, Nigeria, October9-13, 2005, pp. 19-21.

[18] Rodale (2011). Report Provides New Sugar Recommendations For Adults. Retrieved from http://www.rodale.com/recommended-sugar-intake on May 24.

[19] Sawant, S.D. (1983). Investigation of the hypothesis of deceleration in Indian agriculture. Indian journal of Agricultural economics, 38 (4): 475-496.

[20] Studenmund, .A. .H. (2001): Using econometrics a practical guide (fourth edition). Addison Wesley Longman, inc. United States of America.

[21] Swanson, D. A., J. Tayman and T. M. Bryan (2011). MAPE-R: A rescaled measure of accuracy for cross-sectional forecasts. Retrieved from http://forecasters.org/submissions10/MAPE-

REMPIRICALV24ISFSwansonTaymanBryan.doc.pdf on May 19.

[22] Udom, D.S., (2006): Analysis of Nigerian meat production trends: 1961-2004. The Nigerian Agricultural Journal vol 37 (2006): 18-23.

[23] USDA (2006). The economic feasibility of ethanol production From sugar in the united states.

[24] Wayagari J.W., Ayoola G.B., Imolehin E.D. and Misari S.M. (2003a): Economic evaluation of chewing sugarcane production in the central zone of Nigeria. Short Communication of SugarTech. Society of Sugar Research and Promotion. Vol. 5 (I\&2): 81-84.

[25] Wayagari, J.W., Ayoola,.G.B., Imolehin, E.D. and Misari, S.M.(2003b): Economic evaluation of chewing sugarcane production in the central zone of Nigeria. Sugar tech vol 5 (1 and 2): 81-84.

[26] Wayagari, W.J., Busari, L.D., Agborie, S., Amosun A., Kolo, I. and S.M. Misari, (1999): Profitability, resource productivity and efficiency of sugarcane production in Sokoto State - Nigeria. Paper presented at the 33rd Annual Conference of the Agricultural Society of Nigeria. Held at the Conference Hall of National Cereals Research Institute, Badeggi, Nigeria 18-22nd October, (1999).

[27] Yu, L. and P. Ren (2011). Revised Mean Absolute Percentage Errors (MAPE) on Errors from Simple Exponential Smoothing Methods for Independent Normal Time Series. Retrieved from http://www.swdsi.org/swdsi2009/Papers/9Q05.pdf on May 24.

[28] Yusuf, .S.A. and Salau, .A.S. (2007): Forecasting mango and citrus production in Nigeria. A trend analysis. Munich Personal Repec Archive (MPRA). Paper retrieved from http://mpra.ub.uni-muenchen.de/2691/ on $16^{\text {th }}$ august, 2010. 